\title{
Pre-service Science and Mathematics Teachers' Thoughts about Technology
}

\author{
Özge Can Aran*, İpek Derman, Esed Yağcı \\ Department of Curriculum \& Instruction, Faculty of Education, Hacettepe University, Turkey
}

Copyright $\subset 2016$ by authors, all rights reserved. Authors agree that this article remains permanently open access under the terms of the Creative Commons Attribution License 4.0 International License

\begin{abstract}
This study aims to investigate pre-service teachers' opinions about the technology. In this respect, the opinions of pre-service science and mathematics teachers were taken. The study was carried out at a university, located in the capital of Turkey. The data were collected from 20 pre-service teachers in the department of secondary school science and mathematics education. Criterion sampling was used. Interview form was developed to collect data. The results were presented in four themes: the role of technology in pre-service teacher's life, pre-service teachers' preferences about technology, pre-service teachers' technology competence, and pre-service teachers' opinions about use of technology in educational settings. It is expected that the results of the study will contribute to the revision of teacher education programs in terms of technology use and cultivate the learning environment by using technology more effectively.
\end{abstract}

Keywords Pre-service Teachers, Technology, Science Teacher, Mathematics Teacher

\section{Literature Review}

\subsection{Introduction}

Considering information as the smallest building block of individual learning, it is impossible to ignore the effect of information-rich environment on the learning. Information-rich environment means that the mediums include television, radio and traditional media such as gaming tools, and also the Internet and its servers, as well as traditional schools, libraries and museums [26]. Among these mediums, Information and Communication Technologies (ICTs) are the best information sources in that they facilitate communication which is necessary to be a part of the information society $[16,25,34]$. Especially ICTs with internet such as mobile phones, laptop computers and other mobile devices are vital for the mobilization of communication [25] and reaching the richest information environment. Because the internet is a learning source which aids users immensely in acquiring rich information by responding to each individual question, giving instant feedback to each individual response and possessing a hosting capability to individuals' generated content [26]. That is to say, recent technology, which is used innovatively, has a significant potential to support learning in the classroom [16].

Hence, using ICT in the classrooms gains importance day by day for the educational systems around the world [14, 17, $22]$, so integrating technology into instruction is a necessity and teachers should know how to integrate technology in classrooms [16]. Actually, it is expected that not only teachers but also students use technology such as computers as a tool to search, organize, analyze and share or exchange information so schools should educate students as ICT literate which means applying technology effectively [28], in that students should have ICT knowledge and skills to be able to successfully respond to the educational needs of $21 \mathrm{st}$ century [22]. In other words, it is important to have knowledge about technology as well as science and mathematics because all these disciplines are essential for students to adapt their roles in constantly changing world [27, 35]. Hence the pre-service teachers specialize in these disciplines have a critical role on educating next generation as pioneers or leaders who make great contribution to develop a country [35]. In this regard, this research focuses on taking opinions of pre-service science and mathematics teachers about technology and its integration to their professional field.

\subsection{Theoretical Framework}

ICT is an effective tool to improve the quality of teaching and learning [41]. In other words, it is a significant tool for bettering performance, cooperation, learning experience and learning outcomes [2]. Also it provides a thoroughgoing change in school practices and so it helps to prepare students for the future [41]. Surely using traditional print sources are as important as digital sources, yet the contribution of digital tools to the teaching-learning environment cannot be 
denied [16]. For instance, technology provides new learning culture by the help of learning through teacher presentation; self -regulated learning by resources such as books or multimedia-based content and collaborative interactive learning with other learners through ICT [31]. Likewise, Webb [40] emphasized that ICT facilitates learning, enables making connections between knowledge and real life experiences, provides students with the ability to manage their own progress, as well as simplified data collection and presentation process.

Moreover, ICT integration to teaching-learning process can facilitate learning depending on subject matter [21,26]. That is to say, some concepts can be taught by ICT more easily, on the other hand, in order to teach others, simple models can be enough. For instance, in science course a three-dimensional model of the human heart can be a better option for showing the difference between the arterial and a vein than a clip of a beating heart. In contrast, for teaching healthy versus unhealthy heartbeat rhythm, a clip can come to the forefront in terms of facilitating learning. While visual and tactile models serve to remind the components of the heart, the clip depicting a beating heart helps to learn the process [26]. Also as an example for ICT use in mathematics course, the results of Ural [38]'s study conducted in Turkey can be given. This study's results show that secondary school mathematic teachers use software called as Morpa and Vitamin to teach the topics in geometry which requires visuality, PowerPoint presentations to teach solid objects, fractals, and animations and videos on the internet to teach solid materials, triangles, fractals, patterns and decorations, equations and symmetry. Taking all of these applications into consideration, it is vital to use technology in teaching-learning process appropriately [21].

Although ICT is a kind of facilitator for learning when it is used appropriately, there are some obstacles in the worldwide ICT applications. Lack of computers [1, 10, 29, 38] or other ICT equipment, having difficulty about connecting to the internet and lack of access to software programs $[4,7]$ and lack of ICT knowledge or competence are the major obstacles $[1,2,4,29]$. In addition to all these obstacles, teachers think that learning, planning and applying technology take time $[7,38]$ and cause lots of workload which hinders ICT applications [10]. Because of these reasons, many teachers do not prefer to use ICT in their instruction. For instance, the study results of Jimoyiannis \& Komis [17] indicated that the majority of teachers couldn't give at least one example when ICT applications used in their instruction were asked. In addition, the same study also shows that very few teachers mentioned to use presentation software, the internet in order to support their traditional instruction and basic ICT applications such as word processing, spreadsheets...etc. for lesson preparation purposes.

After all, to minimize the drawbacks in ICT application it is necessary for teachers to adapt to their role in ICT integration process. The roles of teacher in this process are related with choosing ICT resources, utilizing them in the classroom and providing students to interact with materials. Indeed, teacher is facilitator who helps to link up between the students and the computers in ICT integration process, along with the fact that they are advisors, mentors, and planners [22]. At this juncture, the belief of teachers about the ICT ability is crucial, because their belief facilitates the process of their decision making concerning how they will behave with their knowledge and skills about ICT. Especially, self-efficacy belief about ICT which is related to attitude towards ICT and competency levels of using computers, features in these decision making process [14], because teachers who think that they are qualified and competent in ICT are more successful in ICT integration process [20]. Besides in the literature there are lots of researches which emphasize the relation between self- efficacy belief and ICT integration. For instance, a study shows that there is average level positive correlation between self-efficacy belief of teachers regarding computers and their attitude towards computer integrated education [9]. Another study reveals that the prospective technology use of pre-service teachers significantly correlates with their self-efficacy beliefs about technology integration [3] similar to the study indicates that prospective ICT integration of pre-service teachers is related with teacher self-efficacy, computer self-efficacy and computer attitudes in education [32]. Also, teachers' experience with technological devices enhances their self-efficacy beliefs about ICT use $[5,19]$ and it also affects ICT integration process [20]. Like teachers' experience with technology, motivation is another important factor that affects ICT use [33]. That is to say, the motivational factors such as teachers' belief concerning their capability to use Information Technology (IT), their satisfaction with the level of resources available or IT, and considering that IT use in teaching is interesting and enjoyable, correlates most positively with ICT use whereas the difficulties encountered in using IT are the negative factors [6].

As seen from the literature review, teachers' positive thoughts, beliefs or perceptions about technology and their self-competence towards technology use can facilitate ICT integration process. Also this study is important to see what kinds of technologies preservice teachers prefer to use and plan to use for educational purposes. This shows us what kinds of technologies they have knowledge about. Therefore, this study has the characteristics of needs analysis and it aims to reveal pre-service teachers' thoughts about technology in order to have a general idea about the prospective ICT integration.

\section{Methods}

\subsection{Design}

This is a qualitative study which aims to identify pre-service science and mathematics teachers' opinions about technology use. The data is collected by interviews, a method used by qualitative researchers most often [13]. 
Hence, this research aims to adress the following research questions:

1. What is the role of technology in pre-service science and mathematics teachers' life?

2. What kinds of technologies do pre-service science and mathematics teachers prefer to use for educational purposes?

3. What are the opinions of pre-service science and mathematics teachers about self-competence regarding technology?

4. What do pre-service science and mathematics teachers think about technology use in educational settings?

\subsection{Participants}

The study was carried out at Hacettepe University located in Ankara, Turkey. The data was collected from 20 pre-service teachers in the departments of teaching physics, chemistry, biology and mathematics. Five pre-service teachers from each department participated in this study. Criterion sampling which is a type of purposive sampling was used in this study. In order to select participants, taking a material development course about technology was used as a criterion. This course aims to introduce properties of some instructional technologies, to give information about the role and the use of these technologies in the science or mathematics teaching processes and to develop 2- and 3-dimensional teaching materials using instructional technologies.

\subsection{Data Collection Procedure}

Semi-structured interview form was used while data was being collected. Before preparing the interview form, the researchers conducted a thorough review of the literature. The interview form includes four main questions and some probes in order to search for the answers to the research questions. These are 1) what do you think about the role of technology in your life? (For what purpose do you use technologies?) 2) What kind of technologies do you prefer to use most for educational purposes? (How do you use these technologies for educational purposes?) and when you become a teacher, what kind of technologies will you prefer to use? 3) What do you think about your technology skills? (How do you evaluate yourselves in terms of your technology skills?) 4) What do you think about the effects of ICT use on instruction? (At what aspects do the ICTs contribute to the instruction? What kinds of limitations do ICTs have?). Also the researchers prepared some warm up questions to establish a rapport between the interviewees and the interviewer.

Before conducting the interview, the dimensions of the inquiries in the interview form were discussed with two computer and technology professionals and two curriculum and instruction professionals, as they checked the interview form and then the pilot testing of the interview form was done with three pre-service teachers. Then face-to face semi-structured interviews were conducted with twenty pre-service teachers in order to gather their perceptions, specific experiences, opinions and behaviors relating to the research questions. During the interview, the researchers used open ended questions that pre-service teachers understand easily, along with probes and follow-up questions to increase the richness of the data during the interview. Interviews took approximately 15 minutes for each person. A voice recorder was also used.

\subsection{Data Analysis}

Firstly, the researchers read the literature related with technology and the themes of the research were identified. After semi structured interviews were conducted, their interview content was transcribed for later coding. In addition, the researchers carefully read the transcripts of interviews by moving back and forth across the documents and analyzed these texts either line by line or word by word deductively in search of codes related with technology. In this step of analysis, the predefined themes acted as guidelines for the researchers to determine the list of codes. After the analysis of documents, the target codes were determined. Then it was counted how many pre-service teachers presented an opinion about each code and these coding decisions in each category were presented with numbers. According to Fraenkel, Wallen \& Hyun [13], counting is seen as an important characteristic of various content analyses. Also it is possible to utilize counting when working self-consciously with frequencies [24], so that the researcher is able to show the similarities and differences in the opinions of science and mathematics pre-service teachers by counting the codes obtained from their opinion statements.

\subsection{Validity and Reliability}

In this research, internal validity was provided by peer debriefing (enabled by talking with pre-service teachers), member checks (enabled by checking of data with stakeholders such as colleagues and pre-service teachers with whom the interviews were conducted). Moreover, the external validity of data was ensured by transferability. Because of this reason, purposive criterion sampling was used to encourage broader applicability. Also pre-service science teachers were selected from different departments such as chemistry, biology and physics to generalize the results to a broader scope. Findings were presented as clear as possible to enable adequate comparison with other samples. Also code and theme lists were presented for comparing whether they were congruent with technology and to enable other researchers to check their code lists.

On the other hand, replicability of study, in other words, its reliability is also important [23]. For internal reliability, the researchers tried to express research questions as clear as possible and they also tried to ask their research questions congruent with the descriptive study design. In the interview, 
they tried to ask questions to all participants by using similar approaches. A voice recorder was also utilized for the interview. Also one of the researchers' colleagues read the 10 pages of raw data. Then inter-coder reliability was calculated, pointing to a figure of .83. Research shows if the reliability is as high as $70 \%$, it is magnificent [24]. For external reliability, the researchers tried to present all data as clear as possible.

\section{Results}

The results of this study are presented in four themes clarifying the research questions. These themes are about the role of technology in pre-service teacher's life, pre-service teachers' preferences about technologies, pre-service teachers' technology competence, and pre-service teachers' opinions about technology use in educational settings. The results regarding these themes are presented respectively as follows;

\subsection{The Role of Technology in Pre-service Teacher's Life}

When the data was examined, it was seen that pre-service teachers' opinions were collected under three levels of importance. This data were presented in Table 1.

According to Table 1, fourteen of twenty pre-service teachers pointed out that technology has an important role in their daily lives. Five teachers expressed that technology was partially important. They also stated that technology enables them to follow daily life events and do research. In contrast, only one biology teacher expressed that she did not turn on the computer if it was not necessary.

\subsection{Pre-service Teachers' Preferences about Technologies Used for Educational Purposes}

Pre-service teachers' preferences about technologies are grouped under two headings. These are "technological devices used most commonly by pre-service teachers' for educational purposes" and "pre-service teachers' preferences about technologies intended for their classroom use when they become teachers". The results for the technological devices used most commonly by pre-service teachers' for educational purposes are presented in Table 2.

Table 2 indicates that all pre-service teachers stated that they used computer for educational purposes. In other words, they stated that they used search engines such as Google, and web pages related with their professions such as web site of the scientific and technological research council of Turkey (TUBITAK) and they also said they used Dailymotion and YouTube for video sharing. Pre-service chemistry and biology teachers stated that they used PowerPoint for educational purposes and also mathematics teachers used Geogebra, Cabri and Mapple as computer programs. In addition to this, one of the physics pre-service teachers gave Multimeters as an example of tools used in laboratory and electronic measurement tools. Additionally, pre-service teachers also mentioned the technologies they intended to use in their lessons when they become teachers. The results are presented in Table 3.

Table 1. The role of technology in the pre-service science and mathematics teachers' life

\begin{tabular}{cccccc}
\hline & Physics & Chemistry & Biology & Mathematics & $\mathbf{f}_{\text {total }}$ \\
\hline Very important & $\mathbf{4}$ & $\mathbf{4}$ & $\mathbf{3}$ & $\mathbf{3}$ & $\mathbf{1 4}$ \\
\hline Partially important & 1 & 1 & 1 & 2 & 5 \\
\hline Not very important & 0 & 0 & 1 & 0 & 1 \\
\hline
\end{tabular}

Table 2. Technological devices used most commonly by pre-service teachers' for educational purposes

\begin{tabular}{|c|c|c|c|c|c|}
\hline & Physics & Chemistry & Biology & Mathematics & $\mathbf{f}_{\text {total }}$ \\
\hline Computer & 5 & 5 & 5 & 5 & 20 \\
\hline Mobile phone & 1 & 1 & 1 & 2 & 5 \\
\hline Projection & 0 & 0 & 0 & 1 & 1 \\
\hline Tablet & 0 & 0 & 0 & 1 & 1 \\
\hline Smart Board & 1 & 0 & 0 & 1 & 2 \\
\hline Overhead projector & 0 & 1 & 0 & 0 & 1 \\
\hline Tools using in laboratory & 1 & 0 & 0 & 0 & 1 \\
\hline
\end{tabular}

Table 3. Pre-service teachers' preferences about technologies intended for their classroom use when they become teachers

\begin{tabular}{ccccccc}
\hline & & physics & chemistry & biology & mathematics & $\mathbf{f}_{\text {total }}$ \\
\hline \multirow{3}{*}{ Accessories } & $\begin{array}{c}\text { Educational software (e.g.simulations, } \\
\text { chembio, geogebra) }\end{array}$ & $\mathbf{2}$ & $\mathbf{3}$ & $\mathbf{1}$ & $\mathbf{2}$ & $\mathbf{8}$ \\
\cline { 2 - 7 } & Video & 3 & 1 & 2 & 0 & 6 \\
\hline \multirow{3}{*}{ Devices } & Smart board & $\mathbf{1}$ & $\mathbf{2}$ & $\mathbf{0}$ & $\mathbf{1}$ & $\mathbf{4}$ \\
\cline { 2 - 7 } & Projection & $\mathbf{2}$ & $\mathbf{1}$ & $\mathbf{1}$ & $\mathbf{0}$ & $\mathbf{4}$ \\
\cline { 2 - 7 } & Overhead projector & 1 & 1 & 0 & 0 & 2 \\
\cline { 2 - 7 } & Tablet & 1 & 0 & 0 & 0 & 1 \\
\hline
\end{tabular}


According to table 3, majority of the sample expressed that they will use educational software $(f=8)$. Pre-service teachers stated they will use educational software for explaining things with 3 dimensions such as molecules and prism and with simulations related to experiments. Also six pre-service teachers expressed that they would use video in their lessons when they become teachers. One of them emphasized that the life of Einstein may be shown via video. Four of the teachers expressed that they would use smart board and projection in their lessons when they become teachers. Moreover, one teacher expressed an opinion about the use of tablet and two of them expressed their opinions on the use of overhead projectors. Two of the teachers expressed opinions about the use of overhead projectors and only one physics teacher expressed an opinion on the use of tablet.

\subsection{Pre-service Teachers' Technology Competence}

Pre-service teachers evaluated their competency level of using technology. Their opinions were classified as very good, good, average, bad and very bad. The results related with this were presented in Table 4.

Table 4 shows that most of the pre-service teachers stated that they used technology on average level $(f=9)$. Two of them evaluated themselves as very competent in terms of technology use. None of them thinks that competency level of using technology is very bad.

\subsection{Pre-service Teachers' Opinions about Technology Use in Educational Settings}

This theme consists of two sub-themes. These are positive opinions and negative opinions on the use of technology in educational settings. Results about these sub-themes are presented as follows;

\subsubsection{Positive Opinions on the Use of Technology in Educational Settings}

The positive opinions of pre-service teachers about technology are categorized in terms of teachers and students. These opinions about technology belonging to teachers are presented in Table 5.

According to the Table 5, the code "technology enables managing time effectively" is expressed by more pre-service teachers compared to other codes $(\mathrm{f}=10)$. A mathematics teacher in the sample presented ideas about this code as follows:

"If 15 problems were normally to be answered in 40 minutes, this doubled when smart board was used in geometry class. This provided students with more different types of questions".

In addition to the codes in table 5 , it was determined that there were some extra codes belonging to subject area. These codes are presented in table 6 .

Table 4. Pre-service Teachers' Self Competence about Technology

\begin{tabular}{cccccc}
\hline Level of Technology Use & Physics & Chemistry & Biology & Mathematics & $\mathbf{f}_{\text {total }}$ \\
\hline Very good & 1 & 1 & 0 & 0 & 2 \\
\hline Good & 2 & 2 & 2 & 2 & 8 \\
\hline Average & $\mathbf{1}$ & $\mathbf{2}$ & $\mathbf{3}$ & $\mathbf{3}$ & $\mathbf{9}$ \\
\hline Bad & 1 & 0 & 0 & 0 & 1 \\
\hline Very Bad & 0 & 0 & 0 & 0 & 0 \\
\hline
\end{tabular}

Table 5. Positive opinions on the use of technology for teachers

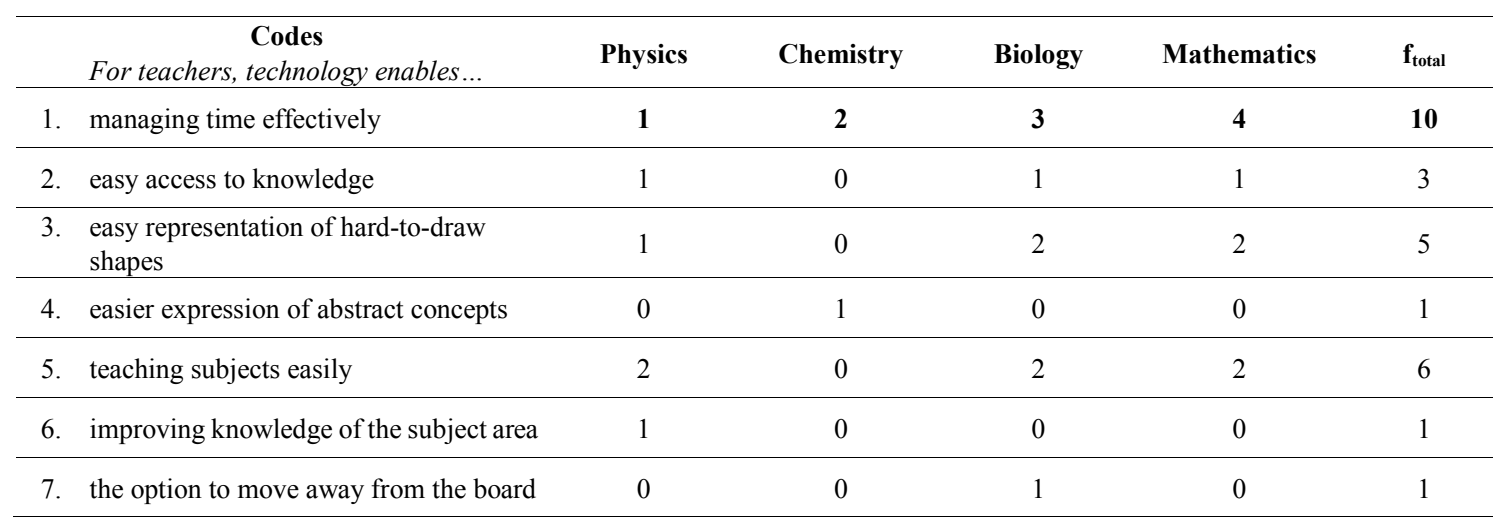


Table 6 shows the codes reflecting the positive opinions of teachers like Table 5. But Table 6 also includes the codes belonging to subject area such as physics and mathematics. For instance, second and third codes are related with experiments and while pre-service science teachers expressed their opinions about this code, mathematics did not express their opinion as could be expected. This is the reason for the fact that Table 6 was submitted separately from Table 5 although both reflect the opinions of teachers.

Most of pre-service science teachers preferred the code "easy demonstration of experiments which cannot be performed in the classroom" ( $\mathrm{f}=6)$. A biology pre-service teacher expressed ideas about this as follows:

"It is economical. We can't carry out such an experiment in the class but there is an example experiment on that thing. The student presses the button and, say, clicks on the acids. If he adds wrong amount of it, the experiment fails. I would certainly like to carry it out in the class but I can't. However, I can do it that way. Because those chemicals are expensive, they are hard to acquire. Time-wise, it is not always possible to use the labs in schools".

Also, the same biology teacher explained the possibility of making experiments safely in virtual environment as follows:

"Those chemicals are also hazardous. Yet, they conduct the experiments by themselves in the program. It has many model experiments. For example, he says he is adding amylase and he adds it. Then, he chooses the wrong chemical, the reaction doesn't occur'.

In addition to this, a mathematics teacher stated that technology ensures practical equation solving as follows:

"There is a mathematics program called Alpha. Difficult mathematical operations such as integral and derivation are linearly entered. And it gives you the solution step-by-step".

Also pre-service teachers expressed the positive opinions about using technology in terms of students. Those ideas are presented in Table 7 .

Table 6. Positive opinions belonging to the subject area on the use of technology for teachers

\begin{tabular}{llcccc}
\hline \multicolumn{1}{c}{ Codes For teachers, technology enables... } & physics & chemistry & biology & mathematics & $\mathbf{f}_{\text {total }}$ \\
\hline 1. & practical equation solving & 1 & 0 & 0 & 2 \\
\hline $\begin{array}{l}\text { easy demonstration of experiments which cannot be } \\
\text { performed in the classroom }\end{array}$ & $\mathbf{2}$ & $\mathbf{2}$ & $\mathbf{2}$ & $\mathbf{0}$ & $\mathbf{6}$ \\
\hline $\begin{array}{l}\text { possibility to perform experiments safely in the virtual } \\
\text { environment }\end{array}$ & 0 & 0 & 1 & 0 \\
\hline
\end{tabular}

Table 7. Positive opinions on the use of technology related with students

\begin{tabular}{|c|c|c|c|c|c|}
\hline Codes For students, technology enables... & physics & chemistry & biology & mathematics & $\mathbf{f}_{\text {total }}$ \\
\hline 4. encouraging students to perform research & 1 & 0 & 0 & 0 & 1 \\
\hline 5. capturing the attention of students & 4 & 3 & 2 & 3 & 12 \\
\hline 6. making information understandable via visuals & 2 & 1 & 2 & 4 & 9 \\
\hline 7. addressing more sense organs & 5 & 0 & 2 & 0 & 7 \\
\hline 8. concretization of abstract knowledge & 3 & 3 & 1 & 3 & 10 \\
\hline 9. retention of knowledge & 5 & 2 & 2 & 1 & 10 \\
\hline 10. better comprehension & 2 & 0 & 2 & 2 & 6 \\
\hline 11. motivation & 2 & 0 & 1 & 2 & 5 \\
\hline 12. entertainment in the classroom & 1 & 0 & 3 & 0 & 4 \\
\hline $\begin{array}{l}\text { 13. feeling relaxed because of being } \mathrm{z} \text { generation or technical } \\
\text { proficient generation }\end{array}$ & 2 & 1 & 1 & 2 & 6 \\
\hline 14. preventing misconceptions by using visuals & 0 & 1 & 0 & 0 & 1 \\
\hline 15. students' taking a break from note taking & 0 & 1 & 1 & 0 & 2 \\
\hline $\begin{array}{l}\text { 16. the teacher to earn more respect with his /her technology } \\
\text { knowledge }\end{array}$ & 0 & 0 & 3 & 0 & 3 \\
\hline 17. equality of opportunity in education & 0 & 0 & 1 & 0 & 1 \\
\hline 18. experience based learning & 0 & 1 & 2 & 2 & 5 \\
\hline 19. establishing relationships with daily life & 0 & 0 & 1 & 0 & 1 \\
\hline 20. reinforcement & 0 & 0 & 0 & 1 & 1 \\
\hline $\begin{array}{l}\text { 21. facilitating communication with the teacher and other } \\
\text { students(email, chat... etc.) }\end{array}$ & 1 & 0 & 1 & 1 & 3 \\
\hline 22. solving more problems & 0 & 0 & 0 & 2 & 2 \\
\hline 23. individualized learning & 0 & 0 & 0 & 1 & 1 \\
\hline
\end{tabular}


According to Table 7, majority of pre-service teachers thought that technology enabled "capturing students' attention" ( $\mathrm{f}=12)$. In addition to this, another majority of pre-service teachers mentioned that technology enabled concretization of abstract knowledge and retention of knowledge $(\mathrm{f}=10)$. A chemistry teacher in the sample presented ideas on technology's attention-capturing qualities as follows:

"Technology captures attention of the people. Once teachers use technology and show something visually, it captures our attention more compared to the teacher who come to the classroom and say something verbally, in that we like computer. In other words when teachers show something via computer, I do not think that someone makes noise too much in the classroom, because different things capture attention of everybody".

\subsubsection{Negative Opinions on the Use of Technology in Educational Settings}

The negative opinions of pre-service teachers about technology are also categorized in terms of teachers, students and learning environment. These opinions about technology for teachers are presented in Table 8 .

According to Table 8, the code "time consuming" is expressed by more pre-service teachers compared to other codes $(f=9)$. According to these results, it can be concluded that while technology use may sometimes be time consuming, other times it enables better time management (see table 5). In other words, provided that teachers know how to use and where to use technology effectively, it can help with time management. A physics teacher summarized this as follows:

"Teachers need to learn how to use technology in order to teach how to use technology. It will take 15 minutes to turn on the computer and set up the projector if the teacher doesn't know how to do it, or he wastes time saying "What do I have to do now?" if he doesn't know how to use a program. It does more harm than good. It wastes time...".

In addition to pre-service teachers' negative opinions for teachers, it was also seen that there were some codes reflecting negative opinions for students. These codes are presented in Table 9.

According to the Table 9, the code "Distractibility" is expressed by more pre-service teachers compared to other codes $(f=7)$ whereas "capturing attention" (see table 7) was thought as a positive aspect of technology by the pre-service teachers. They expressed that if teachers used technology passively, it caused students to lose their attention. In addition to this, pre-service teachers thought that distractibility can occur on the ground that technology provides lots of stimuli all at once.

Table 8. Negative opinions on the use of technology for teachers

\begin{tabular}{llccccc}
\hline \multicolumn{1}{c}{ Codes } & physics & chemistry & biology & mathematics & $\mathbf{f}_{\text {total }}$ \\
\hline 1. & Making teacher lazy & 1 & 0 & 0 & 0 & 1 \\
\hline 2. & Additional workload for teachers & 1 & 0 & 1 & 0 & 2 \\
\hline 3. & $\begin{array}{l}\text { Believing necessity of writing on the board } \\
\text { during instruction }\end{array}$ & 0 & 3 & 0 & 0 & 3 \\
\hline $\mathbf{4 .}$ & $\begin{array}{l}\text { Time consuming due to the lack of } \\
\text { knowledge in technology use, the } \\
\text { digressing... etc. }\end{array}$ & $\mathbf{2}$ & $\mathbf{2}$ & $\mathbf{1}$ & $\mathbf{4}$ & $\mathbf{9}$ \\
\hline 5. & Negative effect on classroom management & 0 & 0 & 2 & 2 & 4 \\
\hline
\end{tabular}

Table 9. Negative opinions on the use of technology for students

\begin{tabular}{|c|c|c|c|c|c|}
\hline Codes & physics & chemistry & biology & mathematics & $\mathbf{f}_{\text {total }}$ \\
\hline 6. Affecting socialization negatively because of technophile & 0 & 0 & 0 & 1 & 1 \\
\hline $\begin{array}{l}\text { 7. Students' losing respect for lack of teachers' technology } \\
\text { knowledge }\end{array}$ & 0 & 1 & 2 & 1 & 4 \\
\hline $\begin{array}{l}\text { 8. Distractibility because of lots of stimuli, teachers' using } \\
\text { technology passively... etc. }\end{array}$ & 2 & 1 & 3 & 1 & 7 \\
\hline 9. Causing boredom in the lesson & 2 & 0 & 0 & 0 & 2 \\
\hline 10. Using technology apart from educational goals & 4 & 1 & 0 & 1 & 6 \\
\hline 11. Blocking the students' thinking & 1 & 0 & 1 & 0 & 2 \\
\hline 12. Not suitable for learning strategies of all students & 0 & 1 & 2 & 0 & 3 \\
\hline 13. No face to face interaction & 0 & 1 & 0 & 0 & 1 \\
\hline 14. Not ensuring the retention of knowledge & 0 & 1 & 2 & 0 & 3 \\
\hline 15. Blocking learning & 0 & 1 & 0 & 0 & 1 \\
\hline
\end{tabular}


Table 10. Negative opinions on the use of technology related with learning environment

\begin{tabular}{clcccc}
\hline \multicolumn{1}{c}{ Codes } & physics & chemistry & biology & mathematics & $\mathbf{f}_{\text {total }}$ \\
\hline $\mathbf{1 6}$. & $\begin{array}{l}\text { Technical problems (malfunction of tools, power cut... } \\
\text { etc.) }\end{array}$ & $\mathbf{0}$ & $\mathbf{2}$ & $\mathbf{2}$ & $\mathbf{2}$ \\
\hline 17. & Lack of technological equipment & 1 & 1 & 1 & 1 \\
\hline 18. & $\begin{array}{l}\text { Instruction with technology use does not prepare students } \\
\text { to standard tests very well }\end{array}$ & 0 & 0 & 0 & 1 \\
\hline 19. & $\begin{array}{l}\text { Instruction with technology is not suitable for all } \\
\text { disciplines }\end{array}$ & 0 & 1 & 0 & 1 \\
\hline 20. & Not possible to emphasize the crucial information & 1 & 0 & 1 & 0 \\
\hline 21. & Lack of technological learning material & 2 & 1 & 0 & 0 \\
\hline
\end{tabular}

A chemistry teacher expressed ideas about distractibility:

"I'm sure, in an educational sciences class, the lecturer will teach better choosing the most important points if he just lectures. I don't know... Instead of teaching only for once in three hours, he can highlight these points twice but he teaches them all from the slides. In a class, he uses 170 slides, which have both important and unimportant ones. He just reads them, which I don't always find useful".

Also, pre-service teachers stated some negative opinions on the use of technology related with learning environment. These codes are presented in Table 10.

According to the table 10, the code "technical problems" is expressed by more teachers compared to other codes $(\mathrm{f}=6)$. So it can be said that pre-service teachers are worried about possible technical problems. A biology teacher expressed ideas about this as follows:

"There are teachers who have prepared their slides but couldn't use them because of a malfunctioning computer. For example, power shortage is a problem".

A pre-service mathematics teacher also mentioned technical problems as follows:

"It is a tool which can be broken. It's very delicate. Sometimes, there can be technical problems and they can't be fixed right away".

Along with these data, the number of codes about pre-service teachers' positive opinions on the technology related with teachers and students were counted. Similarly, the number of codes about pre-service teachers' negative opinions on the technology related with teacher, students and learning environment also were counted. As the number of positive and negative codes were compared, it is concluded that pre-service teachers displayed more positive opinions $(n=30)$ about technology use in the lesson than negative opinions $(\mathrm{n}=21)$.

\section{Discussion and Conclusions}

ICT use in teaching-learning processes becomes more significant with every passing day. Using ICTs properly in the classroom increases the quality of teaching and facilitates the learning. At this point, teachers' self-efficacy beliefs about technology [3, 9, 14, 32], their technology competency $[20,14]$, their experience in technology $[5,19,20]$, and positive opinions about technology $[6,33]$ have a crucial role on their ICT applications. Also literature supports that prospective ICT integration or prospective technology use of pre-service teachers correlate with these factors $[3,32]$. In this respect, this research intended to reveal the pre-service teachers' thoughts about the technology use.

Initially, when the results related with the role of technology in pre-service teacher's life were examined, it was seen that technology had an important role in most of the pre-service teachers' life. Moreover, when asked about their preferences regarding to technological device, pre-service teachers expressed that computer is the most commonly used technological device for educational purposes. They also stated that they used computer for internet search and PowerPoint presentations. This finding is in accordance with the previous researches [11, 17]. Besides pre-service teachers participated in our research emphasized that they used software such as office, geogebra, maple, cabri, vitamin and morpakampus during their university life. Also, $40 \%$ of the sample ( $\mathrm{f}=8$ ) noted that they would prefer software most among the other technological tools for their classroom use when they become teachers. Although they preferred to use educational software most, the total number of the pre-service teachers who intended to use software is low $(\mathrm{f}=8, \% 40)$. This is consistent with the result of Petras [30]'s research about in-service teachers. According to the study of Petras [30], teachers prefer traditional hands on materials rather than technological tools.

In addition to this, most of the pre-service teachers stated that their technology competence was on average level. This result can be caused by their average level experience related with technology just as the study results of Fleming, Motamedi \& May [12] show that the more pre-service teachers use computer technology, the more they become competent in terms of computer technology skills. Also pre-service teachers' average technology competency can be predictor for pre-service teachers' prospective technology use, because study results about in-service teachers in the literature show that the most of the teachers are daily using internet and computer for 1-2 hours [36] and teachers have 
average level self-efficacy belief and attitudes [9, 15].

Next, pre-service teachers stated both positive and negative opinions about technology use in educational settings, but they have more positive opinions regarding technology use than negative ones. The results of this study confirm previous findings about teachers' positive opinions related with ICT $[17,30]$. When their positive opinions were examined in detail, it was seen that technology enables teachers to manage time effectively and captures students' attention. As consistent with this result, John \& Sutherland [18] stated that technology increases student concentration because of the fact that it arouses students' interest toward the lessons. Also according to pre-service mathematics teachers, technology enables them to solve equations practically and for pre-service science teachers, it provides easy demonstration of experiments which cannot be done in the classroom and allows carrying out experiments safely in the virtual environment. When negative opinions about the technology related with teachers were examined, it was seen that technology causes time consumption because of the lack of teachers' knowledge in technology use, the digressing... etc. and also according to pre-service teachers, technology can cause distractions among students because of the presence of too many stimuli, teachers' using technology passively ... etc. Similarly, in the literature teachers' lack of technology competence is emphasized [1, 8]. Moreover another negative opinion about technology was stated that technical problems such as malfunctions of tools, power shortages...etc. disrupted teaching-learning process.

All in all, it can be deduced that pre-service teachers know the importance of technology and think more positively about it. Yet, pre-service teachers should improve their competency regarding technology. Unless they improve their technology knowledge, they will fall behind in this age of technology and so will their students, z-generation. Therefore teacher education programs should be revised for educating pre-service teachers as competent as possible in terms of technology use and teacher education classrooms should also be designed for pre-service teachers to have more experience in the use of different kinds of technological devices. Moreover, it is important to mention about limitation of this study. This research is carried out with limited number of preservice teachers, because 20 voluntary preservice teachers wanted to join this study. Also the preservice teachers in this study were all from the same university. Therefore, further studies can be carried out with more preservice teachers, in the different universities or in the other countries for generalizing the results to the broader scope.

\section{REFERENCES}

[1] Albirini, A. (2006). Teachers' attitudes toward information and communication technologies: The case of Syrian EFL teachers. Computers \& Education, 47(4), 373-398.
[2] Albugami, S., \& Ahmed, V. (2015). Success factors for ICT implementation in Saudi secondary schools:From the perspective of ICT directors, head teachers, teachers and students. IJEDICT, 36-54.

[3] Anderson, S. E., \& Maninger, R. M. (2007). Preservice teachers' abilities, beliefs, and intentions regarding technology integration. Journal of Educational Computing Research, 37(2), 151-172.

[4] Bingimlas, K. A. (2009). Barriers to the Successful Integration of ICT in Teaching and Learning Environments: A Review of the Literature. Eurasia Journal of Mathematics, Science \& Technology Education, 5(3), 235-245.

[5] Bursal, M., \& Yigit, N. (2012). Pre-Service Science and Technology Teachers' Efficacy Beliefs about Information and Communication Technologies (ICT) Usage and Material Design. Educational Sciences: Theory and Practice, 12(2), 1084-1088.

[6] Cox, M., Preston, C., \& Cox, K. (1999, Sep.). What Motivates Teachers to Use ICT? Paper presented at the British Educational Research Association Annual Conference, University of Sussex, Brighton. Retrieved from http://www.leeds.ac.uk/educol/documents/00001329.htm.

[7] Czerniak, C. M., Lumpe, A. T., Haney, J. J., \& Beck, J. (1999). Teachers' beliefs about using educational technology in the science classroom. International Journal of Educational Technology, 1(2), 1-18.

[8] Çağıltay, K., Çakıroğlu, J., Çağıltay, N., \& Çakıroğlu, E. (2001). Öğretimde bilgisayar kullanımına ilişkin öğretmen görüşleri. Hacettepe Üniversitesi Eğitim Fakültesi Dergisi, 21(21).

[9] Çetin, O., \& Güngör, B. (2014). İlköğretim Öğretmenlerinin Bilgisayar Öz-Yeterlik İnançları ve Bilgisayar Destekli Öğretime Yönelik Tutumları. Ondokuz Mayls Üniversitesi Ĕ̆itim Fakültesi Dergisi, 33(1), 55-77.

[10] Dawson, V. (2008). Use of information communication technology by early career science teachers in Western Australia. International Journal of Science Education, 30(2), 203-219.

[11] Dawson, V., Forster, P., \& Reid, D. (2006). Information Communication Technology (ICT) integration in a science education unit for preservice science teachers; students' perceptions of their ICT skills, knowledge and pedagogy. International Journal of Science and Mathematics Education, 4(2), 345-363.

[12] Fleming, L., Motamedi, V., \& May, L. (2007). Predicting preservice teacher competence in computer technology: Modeling and application in training environments. Journal of Technology and Teacher Education, 15(2), 207-231.

[13] Fraenkel, J. R., Wallen, N. E., \& Hyun, H. H. (1993). How to design and evaluate research in education (Vol. 7). New York: McGraw-Hill.

[14] Govender, D., \& Govender, I. (2009). The relationship between information and communications technology (ICT) integration and teachers' self-efficacy beliefs about ICT. Education as Change, 13(1), 153-165.

[15] Hughes, J. (2013). Descriptıve indicators of future teachers'technology integration in the pk-12 classroom:trends from a laptop-1nfused teacher education program. $j$. 
Educatıonal Computıng Research, 48(4), 491-516.

[16] Hutchison, A. C. (2009). A national survey of teachers on their perceptions, challenges, and uses of information and communication technology. ProQuest.

[17] Jimoyiannis, A., \& Komis, V. (2007). Examining teachers' beliefs about ICT in education: Implications of a teacher preparation programme. Teacher development, 11(2), 149-173.

[18] John, P. D., \& Sutherland, R. (2004). Teaching and learning with ICT: new technology, new pedagogy?. Education, Communication \& Information, 4(1), 101-107.

[19] Kahraman, S., Yılmaz, Z., Erkol, M., \& Altun Yalçın, S. (2013). Investigation of Pre-service Teachers' Self-efficacy Beliefs of Educational Internet Use. Elementary Education Online, 12(4), 1000-1015.

[20] Kaya, G., \& Koçak Usluel, Y. (2011). Öğrenme-Öğretme Süreçlerinde Bit Entegrasyonunu Etkileyen Faktörlere Yönelik İçerik Analizi. Buca Eğitim Fakültesi Dergisi.

[21] Kersaint G, Ritzhaupt A, Liu F. (2014, Jan 1), Technology to Enhance Mathematics and Science Instruction: Changes in Teacher Perceptions after Participating in a Yearlong Professional Development Program. Journal Of Computers In Mathematics And Science Teaching. 33(1): 73-101. Available from: ERIC.

[22] Khan, N. (2009). Information and Communication Technology (ICT) in Teacher Education in the Centra of Globalisation. Online Submission.

[23] LeCompte, M. D., \& Goetz, J. P. (1982). Problems of reliability and validity in ethnographic research. Review of educational research, 52(1), 31-60.

[24] Miles, M. B., \& Huberman, A. M. (1994). Qualitative data analysis: An expanded sourcebook. Sage.

[25] Naylor, T. D. (2010). Digital Diversity. Wilfrid Laurier University Press.

[26] Neuman, D. (2011). Learning in information-rich environments: I-LEARN and the construction of knowledge in the 21st century. Springer.

[27] Niess, M. L. (2005). Preparing teachers to teach science and mathematics with technology: Developing a technology pedagogical content knowledge Teaching and teacher education, 21(5), 509-523.

[28] P21. (2014, January 14). Information, Media and Technology Skills. The Partnership for 21st Century Skills. Retrieved from http://www.p21.org/about-us/p21-framework/61

[29] Pelgrum, W. J. (2001). Obstacles to the integration of ICT in education: results from a worldwide educational assessment. Computers \& education, 37(2), 163-178.
[30] Petras, C. L. M. (2010). A Descriptive Study of Science and Mathematics Teachers Pedagogy, ICT Use and Perceptions of How ICT Impacts Their Teaching. ProQuest LLC. 789 East Eisenhower Parkway, PO Box 1346, Ann Arbor, MI 48106.

[31] Popper, V., Strohmeier, D., \& Spiel, C. (2012). Using the internet positively in schools: The case for notebooks. In A. Costabile, \& B. A. Spears (Eds.), The impact of technology on relationships in educational settings (pp.77-90). Newyork: Routledge.

[32] Sang, G., Valcke, M., Braak , J., \& Tondeur, J. (2010). Student teachers' thinking processes and ICT integration: Predictors of prospective teaching behaviors with educational technology. Computers \& Education, 54(1), 103-112.

[33] Sang, G., Valcke, M., Braak, J., Tondeur, J., \& Zhu, C. (2011). Predicting ICT integration into classroom teaching in Chinese primary schools: Exploring the complex interplay of teacher-related variables. Journal of Computer Assisted Learning, 27(2), 160-172.

[34] Spears, B. A., Kofoed, J., Bartolo, M. G., Palermiti, A. L., \& Costabile, A. (2012). Positive uses of social networking sites: Youth voice perspectives. In A. Costabile, \& B. A. Spears (Eds.), The Impact of Technology on Relationships in Educational Settings (pp. 7-21). Newyork: Routledge.

[35] STEM (Science, Technology, Engineering and Math) (2015, January). Science, Technology, Engineering and Math: Education for Global Leadership. Retrieved from http://www.ed.gov/stem

[36] Tezci, E. (2009). Teachers' effect on ICT use in education: The Turkey sample. Procedia-Social and Behavioral Sciences, 1(1), 1285-1294.

[37] Tondeur, J., Van Braak, J., \& Valcke, M. (2007). Curricula and the use of ICT in education: Two worlds apart?. British Journal of Educational Technology, 38(6), 962-976.

[38] Ural, A. (2015). Ortaokul Matematik Öğretmenlerinin Bilgi İletişim Teknolojisi ve Psikomotor Beceri Kullanımlarının İncelenmesi. Turkish Journal of Computer and Mathematics Education, 6(1), 93-116.

[39] Usun, S. (2009). Information and communications technologies (ICT) in teacher education (ITE) programs in the world and Turkey: (a comparative review). Procedia-Social and Behavioral Sciences, 1(1), 331-334.

[40] Webb, M. E. (2005). Affordances of ICT in science learning: implications for an integrated pedagogy. International journal of science education, 27(6), 705-735.

[41] Yusuf, M. O. (2005). Information and Communication Technology and Education: Analysing the Nigerian National Policy for Information Technology. International Education Journal, 6(3), 316-321. 